\title{
Territorial and Non-territorial Aspects in the Autonomist Proposals of the Sudeten German Party, 1937-38
}

\author{
Oskar Mulej (D) \\ University of Vienna, Austria \\ Email: oskar.mulej@univie.ac.at
}

\begin{abstract}
The article focuses on two sets of autonomist demands that the far-right Sudeten German Party (SdP) in Czechoslovakia put forward during 1937-38. Its central thesis being that both sets were marked by a profoundly close interplay between territorial and non-territorial approaches at accommodating national diversity, it sets to explore this relationship, highlighting the underlying dynamic. Although the 1937 Volksschutzgesetze posed as an ostensibly "pure" case of non-territorial autonomy, whereas the 1938 Skizze über Neuordnung der innerstaatlichen Verhältnisse entailed major territorial provisions, in both cases the practical end-goal implied territorial autonomy. A closer look into their inner logic and intellectual origins however, also reveals a shared, essentially non-territorial underpinning. While the SdP agenda was firmly centered on national territory, its specific völkisch and organicist understanding of nationality manifested a clear preponderance of non-territoriality. Both sets of autonomist demands may thus be treated as a potentially maximalist combination of territorial and non-territorial arrangements resting on a fundamentally non-territorial notion of Volkspersönlichkeit. Encompassing all the members of the national group, the latter was simultaneously conceived as the basic carrier of political will. Volksschutzgesetze and Skizze thus represented clear examples of illiberal (re-)conceptualization of national autonomy, informed by contemporary völkisch sociological, legal, and political thought.
\end{abstract}

Keywords: Czechoslovakia; Sudeten Germans; non-territorial autonomy; territorial autonomy; ethnonationalism

"Our home soil is the original property [Urgut] of the German people and must remain so forever," stressed Konrad Henlein $(1939,17)$, the leader of the Sudeten German Party (SdP) in a speech that he held in early 1937 in Aussig/Ústí nad Labem. Such an emphasized stress on "home soil" was nothing surprising for a politician, speaking on behalf of the Sudeten Germans, a distinctly territorial national group, whose settlement patterns exhibited high degrees of compactness and homogeneity. It was even less surprising for a leader of a party, whose political rhetoric had been centering on the struggle for maintaining the borders and integrity of the compactly Germanspeaking territories in Czechoslovakia. For these reasons it seems so much more perplexing that the very same speech had served to announce a set of autonomist demands that the party a couple of weeks later presented in the Czechoslovak parliament and which did not contain a single reference to territory. Jointly known as Volksschutzgesetze (Laws for the protection of nationality), the six draft laws called for a far-reaching re-organization of the state along national lines on the basis of the personal principle. As such they represented a clear example of non-territorial autonomy (NTA). How come a political movement so dearly attached to territory came to formulate its autonomist demands in purely non-territorial terms? The question appears even more relevant as a year later

(C) The Author(s), 2022. Published by Cambridge University Press on behalf of Association for the Study of Nationalities. This is an Open Access article, distributed under the terms of the Creative Commons Attribution licence (https://creativecommons.org/licenses/by/4.0/), which permits unrestricted re-use, distribution, and reproduction in any medium, provided the original work is properly cited. 
the SdP put forward another set of demands to the Czechoslovak government, which this time also entailed radical territorial provisions.

The two legal and organizational principles underpinning autonomist and similar arrangements for accommodating diversity - the territorial and the personal (non-territorial) - represent two opposing ways of defining the carrier(s) of autonomy. Both being collective rights approaches, the territorial principle defines membership in the autonomous group on the basis of territorial belonging (e.g., citizenship or residence in an autonomous territory). Personal principle, on the other hand, is essentially non-territorial, as it is the national group per se, regardless of where in the entire state territory its members may reside, that acts as carrier of autonomy. The autonomous entity is thus formed through personal affiliation of its members with a given nationality and comprised by the entirety of persons belonging to it - thus the term "personal principle." As "ideal types", territorial and non-territorial autonomy are commonly seen as exclusionary opposites. In reality, however, territorial and non-territorial approaches always stand in a certain complementary relationship, revealing a mutual dynamic, as best seen in the various programs for tackling the national question that had emerged before WWI in the multinational Habsburg and Russian empires. Simultaneously, as these same examples show, it is always only one of the two principles that acts as fundamental in each particular instance of autonomist arrangements.

This article examines the two sets of autonomist demands with particular attention paid to the theoretical and ideological tenets underpinning them. In particular it aims to explore the intertwinement between territorial and non-territorial approaches and their complex interplay. The principal goal thereby is to show, how the two not only complemented each other, but acted interdependently, whereby the platform on which the entire edifice rested was essentially nonterritorial. It will show that, while the practical end-goals to a major extent aimed at territorial autonomy, the essentially non-territorial fundament of the SdP demands were rooted in deeper ideological reasons and theoretical considerations. It was the specific illiberal and völkisch conception of nationality and its relation to statehood that largely underpinned it.

The article is composed of two main parts. The first gives an in-depth presentation of the subject matter along with some broader context. Beginning with a general outline of national politics in the Bohemian lands in the early $20^{\text {th }}$ century, it offers a short overview of autonomist demands that had emerged within the framework of German politics in Czechoslovakia, while particularly looking at the autonomist discourse of the Sudeten German Party. This is followed by an outline of the 1937-38 developments and a detailed account of the content of the two sets of autonomist demands. Particular focus is thereby devoted to the clearly non-territorial basis of the 1937 Volksschutzgesetze and the maximalist combination of NTA and territorial autonomy explicated in the 1938 "Sketch" (Skizze). ${ }^{1}$

The central discussion unfolds in the second part, where the question concerning territorial and personal principles and their mutual relationship within the SdP's autonomist ideas is unraveled. Since this question directly concerns the underlying theories, the intellectual background of SdP conceptions of national autonomy is closely examined as well. A closer analysis will show that, while the practical end-goals in both sets of demands contained territorial autonomy, their shared basic underpinning was essentially non-territorial. Illuminating the intellectual origins and path and identifying two main intellectual currents that had informed the SdP autonomist conceptions, centrality of the notion of "ethnic personality" (Volkspersönlichkeit) will be emphasized and explained in the concluding part of the article.

I.

The modern history of the Bohemian lands had been highly marked by the nationalities struggle, as well as by continuous attempts to contain it. Most of these had been territorially centered and aimed at either dividing the historical lands of the Bohemian crown along ethnic lines or at maintaining their territorial integrity. At the same time, non-territorial approaches had been present as well. Apart from the never-implemented compromise in Bohemia (1871), of which 
only the nationally-divided school boards were introduced, the Moravian Compromise of 1905 and the 1914 settlement in Budějovice/Budweis represent the clearest examples (Kuzmany 2016, 46-51, 58-59).

The post-WWI realities were distinguished both by the continuity of the nationalities struggle and the preponderance of territoriality in the attempts of finding a solution to it. Foundation of the new nation-state of Czechoslovakia, encompassing the entire historical Bohemian Kingdom with addition of the former Upper Hungary and Subcarpathian Ruthenia, resulted in the creation of major "national minorities" that did not form part of the Czechoslovak "state nation." In order to improve their lot, these employed various strategies. All in all, these bore a predominantly territorial mark, be it of separatist - especially during the immediate post-war years - or of autonomistfederalist nature. Some attempts, particularly those that developed within the framework of German minority politics, however also incorporated non-territorial approaches. These were present in autonomist programs of politicians from all across the political spectrum, ranging from German Social Democratic Party, the liberal German Democratic Freedom Party, the German Christian-social People's Party all the way to the national socialists (Lipscher 1981, 346-350; Houzvicka 2016, 147; Vierling 2014, 93).

The common feature of most of these programs and demands was that they primarily centered on the national territory as the carrier of self-rule, while merely adding certain non-territorial provisions for those Germans living outside the areas of compact settlement. A peculiar exception to this rule were the ideas advocated by Franz Jesser, prominent member of the German National Socialist Workers Party (DNSAP) - a party that otherwise stood for pronouncedly territorial forms of self-rule. Jesser's position, stressing the advantages of non-territorial solutions, at least partly rested on his conception of nationality as "an individuality living according to its own laws" whose relationship towards the state was that of "original and permanent," towards "the derivative and changeable" (Jesser 1926). As early as in 1917 Jesser thus expressed reservations towards Wilson's principle of self-determination, on the grounds that the American understanding of nation "was founded not on ethnic [volklicher] but on a territorial basis" (Kracik 1999, 71).

A similar basic conception of Volkstum as the primal communal bond also distinguished the ideology of the Sudeten German Party, whose discourse was marked by an interesting mix of territorial and non-territorial elements. Formed in 1933 and representing a highly heterogeneous assortment of various nationalist political groups and ideological orientations (Gebel 1997, 376; Vierling 2014, 98), the Sudeten German Homeland Front (Sudetendeutsche Heimatfront; SHF) presented itself not as an ordinary political party but as a broad popular movement, aiming to unite all the Germans in Czechoslovakia under its banner. The proclaimed objective was creating a united Sudeten German Volksgemeinschaft, "a unified uniformly organized and led Sudeten-Germandom, which knows how to protect its right and its homeland" (Henlein 1937, 21), at the same time claiming the full mandate to speak on its behalf. The latter claim was eventually substantiated by electoral results, with SdP winning more than two thirds of the German vote and the highest percentage out of all Czechoslovak parties in the 1935 elections.

Looking at the key party documents, which had voiced demands for the recognition of Germans as a constitutive nation of Czechoslovakia that should be granted autonomous rights, one can easily spot the explicit emphasis on both territorial and non-territorial aspects. While already the first public proclamation in 1933 had contained the term "ethnic personality" (Volkspersönlichkeit) (Henlein 1937, 10), Henlein at a rally in Böhmisch Leipa/ Česká Lípa in October 1934 demanded the re-organization of Czechoslovakia into a nationalities state, consisting of "national bodies" (Volkskörperschaften). These were to be constituted as "self-ruling bodies with public legal character" (Henlein 1937, 35). Next to this the same speech however also clearly stressed the "inviolability of our Lebensraum and our national soil" (Henlein 1937, 40). Notions such as "homeland" (Heimat), "home soil" (Heimatboden), "national soil" (Volksboden) and "ethnic border" (Volkstumsgrenze) continuously occupied a central place in the SdP discourse, aimed at maintaining the borders and integrity of the compactly German-settled territory in Czechoslovakia. 


\section{The 1937 Volksschutzgesetze}

At the beginning of 1937 the German social democrats, Christian socials, and agrarians put forward a joint memorandum, subsequently reaching an agreement with the government, which promised certain concessions to the German national group. These above all concerned proportional representation in administration, in public enterprises, and in state companies. More government funds were to be channeled into majority-German parts of the country, especially for the sake of combatting unemployment (Kracik 1999, 342-343; Kučera 1999, 145-149; Haslinger 2010, 400).

As an immediate reaction to this agreement (Leoncini 1988, 118; Wiskemann 1938, 257) Henlein announced the intent of his party to develop and put forward a more substantial and lasting solution to the nationality problem in the form of "völkisch self-rule" (völkische Selbstverwaltung). Whereas the government promises to the activist parties entailed purely administrative measures, which could easily be revoked by any future government, Henlein accentuated the need for a legislative solution. In his speech at the party rally in Aussig/Ústí nad Labem on February 28 (Henlein 1939, 7-21), he delineated the key tenets that such a solution was to be based on. Each national group of Czechoslovakia was to be legally recognized and instituted "as a body of public law with unified representation." Particularly he emphasized the need for national cadasters, i.e. registries enabling "inclusion of [all] the members of a nation on the basis of personal ethnic affiliation [Zusammenfassung der Angehörigen einer Nation auf Grund persönlicher völkischer Zugehörigkeit]" as the "indispensible precondition for a just organization of self-rule" (Henlein 1939, 18-19). He thereby specifically emphasized that this kind of self-rule did not contradict the unity of the state as it did not demand any kind of special status for any part of its territory. At the same time, he however also demanded "protection of our homeland and guarantee of our ethnic border" (Henlein 1939, 20).

Two months later Henlein's announcement came true as demands were formally put forward in the Czechoslovak Parliament in form of six draft laws. Coming to be jointly known as Volksschutzgesetze after the official title of the first of them, the bills were meant not only to provide a legal basis for the promises included in the February Agreement, but to constitute the national groups inhabiting Czechoslovakia as separate legal entities. The bills were a rather fast product, having been put together in haste with the aim to put forward a positive legal alternative to the February Agreement that would have enabled the SdP to reclaim the initiative in German minority politics something confirmed both by contemporary diplomatic sources, as well as later testimonies. ${ }^{2}$ While the last three of the bills ${ }^{3}$ more or less aimed at legally instituting the main promises of the February Agreement, such as participation of nationalities in public institutions, proportional to their share in entire state population and the right to appeal to the Constitutional Court in cases concerning minority rights, it was the first three that contained the crucial provisions for national autonomy, at the same time also representing the main subject of dispute with the Czechoslovak government and Czech legal experts (Tóth, Novotný, and Stehlík 2012, 366).

The most important was the "Law on the protection of the national rights [Volkstumsrechte] through formation of associations of public law" or shortly "Volksschutzgesetz" proposed by Ernst Kundt. ${ }^{4}$ In line with it, each of the main national groups of Czechoslovakia would form a national association (Verband), representing a person of public law. These would initially be founded by the parliamentary representatives of each nationality, which would at the same time form the association Board, or Vorstand. The Board of each national association would in turn elect a Speaker (Sprecher) and his Deputy, who - while themselves not being members of parliament (this being explicitly forbidden) - would be given the mandate to represent their national communities and their interests towards the state organs, as well as the other national associations. Through their ruling organs the national associations would therefore be given the full mandate to represent their national communities and to co-rule the state, while having broad, far-reaching, and not clearly limited powers in administering the "internal" life of a given nationality in the fields of culture, education, social policy and economy. This would among other be done via numerous compulsory organizations of corporatist character. The rather vaguely delimited authority of the Speaker - an 
institution that the French envoy in Prague De Lacroix paralleled to the Ottoman Millet system (Brandes 2010, 70) - accompanied by weak democratic legitimation (Osterkamp 2009, 218), lack of control mechanisms and accountability towards membership clearly hinted at "Führerprinzip" (Petráš 2009, 250; Kracik 1999, 350).

After being consolidated, the national associations would legally comprise all the citizens of a given nationality. According to the "Law concerning national belonging of the state citizens and the national cadaster," the second bill put forward by Fritz Köllner, ${ }^{5}$ every adult citizen would have the right and the duty to declare his or her nationality and enroll into the corresponding national registry. This decision was meant to be a one-time and irrevocable one. It was furthermore not an entirely free one, as it had to be "truthful," corresponding to the language, used in family, and could ultimately also be decided by a special Cadaster court. In the words of the prominent contemporary scholar on nationality question, Karl Gottfried Hugelmann $(1937,566)$, this meant an "overcoming of the subjective and the objective theory in a higher synthesis." The ultimately involuntary manner of determining nationality might also be understood as a legacy of the Moravian compromise. Yet, the crucial difference lay in the one-time and irrevocable character of the declaration, which was only to be done by the current generations of adult citizens. After being formed, the national registries and thus the membership in the national associations were to be fixated and sealed, with nationality of all the future generations being determined in advance by that of their forefathers (cf. Boyer and Kučera 1997, 368) ${ }^{7}$.

Lastly, the "Law concerning the protection against any kind of denationalization," put forward by Rudolf Sandner, ${ }^{8}$ thereby also included provisions for protecting the "national property" (nationaler Besitzstand). The latter term - an old nationalist battle slogan - thus gained fresh force, now for the first time being framed as a legal category, designating a concrete object, to be protected by criminal law. It was thus not merely the souls, but also material property, that was to be prevented from being denationalized. The latter again encompassed not merely land, factories, and other enterprises, but extended even to jobs. Had a certain workplace for a given amount of time already been occupied by a member of a given nationality, it should have been recognized as belonging to that nationality - as part of its "property." The foreseen legal institutionalization and protection of "national property" implied a major hampering of the market, as it would have created a peculiar kind of national autarchy, "which would furthermore not be defined territorially but personally" (Petráš 2009, 251).

Taken together, the Volksschutzgesetze thus combined provisions for broad and far-ranging national autonomy with consociationalist arrangements (de facto national sectioning of the parliament, strict national proportionality in all state institutions and public enterprises). In some of their aspects they might offer the appearance of a mere retour towards provisions that had already been in force in Austrian times, such as the right of nationalities - and not solely individuals - to appeal to the Supreme Court (Stourzh 1985, 195-196). In the same vein they might also be interpreted as aiming to secure what various legal theoreticians and national activists of old Austria had longed for but had never fully achieved (recognition of nationalities as legal persons). The SdP proposals however went considerably further. Their "package" indeed included considerably more than any of the previous modern examples of national autonomy, containing novel elements that were clearly illiberal and also potentially undemocratic. As such they bore substantial and farreaching implications concerning the inner structure of the state, its mode of functioning and its very foundations. Apart from the fact that they effectively negated the Czechoslovakia's official nation-state character, their "revolutionary character" lay in that they posited nationalities as the basic carriers of political will and sovereignty. ${ }^{9}$ These were attributed an essentially political character as basic agents of statehood. Or, in the words of Hugelmann (1937), who gave his support to the SdP bills, these did not imply merely (broad) autonomy but something more:

Here we encounter a novel form of authority exercised by the national association. It is not autonomy in a narrower or broader sense $[\ldots]$ but representation of the national group in its 
ethnic rights [Volkstumsrecht] within the state and towards its organs. Here, the national group as such becomes involved in the life of the state. (568)

It remains unclear whether the national associations were envisaged to bear direct legislative and executive powers (Osterkamp 2009, 217). The bills spoke only of "delegated competences" (übertragener Wirkungskreis), while the later explanations by the protagonists denied that they were supposed to have "any normative or executive functions" (Prager Presse, November 13, 1937). It was however quite certain that in practice they could come to indirectly control both branches (Osterkamp 2009, 220). The SdP bills left the question concerning powers of central government institutions and their future role entirely unaddressed. It was certain, however, that these were to be significantly curtailed: in particular, the state parliament, while still nominally existing in its envisaged form of a central representative body, would become factually divided into national representations that would simultaneously form the Boards of autonomous national associations. The Parliament would thus be transformed from popular representation of one, indivisible demos (Staatsvolk) into a place of institutionalized struggle between particular ethnonational groups. In words of Latvian German activist Paul Schiemann, one of the main protagonists in the interwar minorities' movement, this essentially meant "putting nationalism against nationalism" (Schiemann 1937).

The national group was furthermore to be constituted on a binding and essentializing definition of nationality, which would, in contemporary verdict by Elisabeth Wiskemann ${ }^{10}(1938,258-259)$, have created such barriers between particular nationalities as did not exist even between citizens of different states. The most outstanding specificity of Volksschutzgesetze, however, was the allencompassing nature of the foreseen national autonomies, which stretched far beyond the spheres of culture and education and was coupled by virtual omnipotence of the national associations as their executors towards their individual members. The latter, possessing dual legal status as "citizens-conationals" (Staatsbürger-Volksgenossen) (Thiele 1938, 487) would thus be turned into "passive objects of care" (Tóth, Novotný, and Stehlík 2012, 250). Theodor Veiter, a renowned expert on nationality law from Austria, endorsed this as an expression of what he termed "new conception of nationality" (neue Volkstumsauffassung), in line with which the national community possessed an "absolute claim" over its individual members, who could also be coerced into putting themselves at their communities' disposal (Veiter 1938, 216-217).

Volksschutzgesetze experienced varied reactions in the German-speaking press. The liberal Bohemia (April 29, 1937) emphasized the features deemed compatible with its outlook, particularly points common to the earlier autonomist proposals by the liberal politicians Bruno Kafka and Ludwig Spiegel, as well as the visible legacy of the pre-war ideas of the Austrian Social Democrat Karl Renner. In particular the absence of any reference to race was pointed out, which according to the newspaper implied openness towards Bekenntnisdeutschtum (identification with Germandom by individual choice) - a matter of great relevance to Bohemia's largely Jewish readership. On the other hand, the previously outlined illiberal traits that distinguished the SdP proposals from previous modern examples of NTA were explicitly considered as virtues by bulk of their supporters both within and outside Czechoslovakia. In particular this applied to the great degree of attention and support that they enjoyed within the framework of the German minorities' representation in the Association of German National Groups in Europe (Verband der deutschen Volksgruppen Europas) and the European Nationalities Congress (ENC). The ENC's unofficial mouthpiece Nation und Staat devoted an entire issue to them. They furthermore enjoyed considerable resonance in the political and scholarly press in the German Reich.

The same illiberal traits, recognized as virtues by supporters provided the main grounds for critique by their opponents. Emil Sobota, the Czechoslovakia's leading legal expert on the nationalities question needs to be particularly pointed out in this regard. He wrote a series of expert opinions for the government and in 1938 also published a book "National Autonomy in 
Czechoslovakia?" (Národnostní autonomie v Československu?), offering a direct critique of the Volksschutzgesetze, in which he singled out all those features that made them incompatible with the liberal state. While the SdP bills were swiftly rejected by the Steering and Constitutional Law Committees of the Czechoslovak House of Representatives (Tóth, Novotný, and Stehlík 2012, 367) and the Parliament kept postponing their discussion (Wiskemann 1938, 259), they received a wide resonance in both Czechoslovak and foreign press. The public debate reached its height in the autumn months of 1937 and prolonged itself well into 1938.

\section{The 1938 Autonomist Demands: Karlsbad Demands and Skizze}

In the meantime, major moves took place on the stage of European politics. Hitler's proclamation of Germany as "protective power" for all the ethnic Germans, followed by annexation of Austria in March 1938, unleashed a fresh wave of nationalism among the Sudeten Germans, simultaneously making SdP their uncontested representative by virtually eliminating competition, except for the weakened Social Democrats. At least since November 1937 (Brandes 2010, 50) Henlein had been working hand in hand with Hitler, subordinating his movement to the strategic goals of the Reich. For this same very reason, the further autonomist demands presented during 1938 and negotiations that accompanied them are primarily to be seen as an instrument for pressuring the Czechoslovak government with the true ultimate goal of secession. Announced by Henlein at a party rally in Karlsbad/Karlovy Vary in April 1938 in form of eight points, the demands were thoroughly elaborated in a secret memorandum presented to the Czechoslovak government in June of the same year under the title Sketch for the reconstruction of the internal order of the State on the basis of the Eight Points, set out by Konrad Henlein, leader of the Sudetendeutsche Partei in his speech on April $24^{\text {th }}, 1938$, at Karlsbad. ${ }^{11}$

The demands sparked the beginning of intensive negotiations between SdP and the government - ultimately involving president Beneš himself - that lasted throughout the summer and involved a number of counterproposals by the government side. With Henlein receiving instructions from Berlin and closely coordinating the activities with the foreign policy of the Reich, the negotiations shattered, although in the end the Czechoslovak side agreed to virtually all of the Sudeten German demands. The ensuing crisis resulted in the Munich agreement between the great powers, forcing Czechoslovakia to cede its compactly settled German territories to the Third Reich. The tactical nature and geopolitical conditioning of the 1938 autonomist reform plans however did not mean that their creators within and beyond the SdP ranks did not invest considerable efforts and theoretical resources into developing them. While at least some of the key protagonists may not have been fully aware of the extent of Henlein's dealings with Hitler and their actual agenda, their proposal, a plan obviously unacceptable to the Czech politicians, presented an elaborate product, drawing from multiple sources of legal and historical knowledge.

The Karlsbad demands were presented as a program, aiming at implementing the principle of equality (Gleichberechtigung) to all the nationalities of Czechoslovakia. ${ }^{12}$ They contained both explicit territorial and non-territorial demands. While the former was clearly expressed through Point Three demanding "demarcation and recognition of German national territory," 13 the Point Two and Point Five put forward clearly non-territorial demands: "recognition of the Sudeten German national group as a legal subject, in order that its equality in the state should be safeguarded" (Point 2) ${ }^{14}$ and "creation of legal safeguards for those Sudeten German citizens who live outside the closed settlement area of their national group" (Point 5). The eighth point thereby also demanded "full freedom of confession to the German nationality and the German world-view," 15 by which adherence to National Socialism was meant (Osterkamp 2009, 230). In the beginning of June Ernst Kundt presented the Czechoslovak prime minister with a formalized and more elaborate plan for reforming the state in the spirit of "national equality" (Brandes 2010, 195). Skizze put forward the Karlsbad demands in a more systematical way, explaining each of the points and presenting a full scheme for re-organizing the state and creating organs of national autonomy 
on all administrative levels. At the same time, it was put in more moderate wording than the Karlsbad demands, leaving out all references to National Socialism. ${ }^{16}$

The reorganization of the state was to proceed via constitutional and ordinary laws that would have institutionalized the division of the state citizenry (the sovereign "Volk") into individual national units - "nations and national groups" (Völker und Volksgruppen), simultaneously ensuring that this system could not be changed via outvoting. ${ }^{17}$ The national units as the basic components of the "sovereign Volk" were to constitute legal persons, comprising all the members of each nationality residing within the borders of Czechoslovakia. In contrast to the undefined provisions of the Volksschutzgesetze, the new proposal was elaborate, clearly outlining the division of powers between the state government and the organs of national autonomy. Out of the three government branches, only the judicial was to be kept unified, whereby national sections were to be established on its higher levels, including the constitutional court. ${ }^{18}$ The legislative and executive branches of government were to be divided between the organs of state and those of national self-rule. ${ }^{19}$ The legislative power would be divided between the central parliament as a whole and the national sections (curiae) within it. Each of these would simultaneously build a separate National Representation (Volksvertretung) for its own nationality, authorized with normative powers in all the areas that were to be constitutionally conceded to the national groups alone. Each National Representation would elect a Chairman (Vorsitzender der Selbstverwaltung), that would also be given a ministerial position in the state government. As the supreme holder of executive power within the national self-rule, the Chairman was simultaneously to act as the head of the autonomous national government, the Directory (Direktorium der Selbstverwaltung), whose members he was to personally pick. Ministries of Health, Social Policy, and Education were to be dissolved with their powers fully transferred to the organs of national autonomy. Within their Directories Supreme Offices of Self Rule (Oberste Selbstverwaltungsämter) were to be created and function as ministries responsible for education, social policy, economy, agriculture, etc. All other government ministries, except for defense, foreign policy, and finance were to be sectionalized on the basis of nationality. In the latter two, arrangements to represent the special economic interests of the individual national territories had to be secured.

In addition to division of the central powers between the state and the nationalities, the division was to take place on the lower administrative levels as well, resulting in establishment of territorial national self-rule. This was to take place on the municipal, district and provincial level. While the end-version of the proposal, keeping with the established administrative order, lacked the administrative level of "national areas" (Volksgebiete) unifying all the territorial units belonging to a particular nationality that had been present in one of its earlier drafts, it foresaw the establishment of autonomous national administrations on the provincial level. Thus, in Bohemia power would be divided between the provincial state authorities and the Czech and German national provincial self-governments. These, headed by an elected Provincial Governor (Landeshauptmann) and consisting of national Provincial Committee (Landesausschuss) and Provincial Assembly (Landesvertretung) would autonomously rule over the Czech and the German parts of the province respectively, consisting of districts and municipalities belonging to the given nationality. There the administration would be entirely in the "national hands," amounting to full territorial self-rule, also encompassing state tasks on the lower administrative levels. At the same time, the competences of the national provincial self-government in exclusively national matters would pertain to all the members of a given nationality residing in the province, regardless of location, and would thus be non-territorial: "Insofar as the powers of the national self-governments are based on the personal principle, the authority of the national provincial administrations extends to all the citizens of a given nationality in Bohemia. ${ }^{\text {"20 }}$ While each national self-administration would use only its own language, reciprocal minority language rights would be secured for the national minorities, whereas for Prague special provisions would be instituted that would express "the fact, that the town of Prague belongs to all nations and national groups living in Czechoslovakia." ${ }^{1}$ 
II.

In line with the central thesis of this article - namely that the autonomist ideas of the Sudeten German Party were marked by a profoundly close interplay between territorial and non-teritorial approaches at accommodating national diversity - it is worth closely examining both the 1937 and the 1938 demands in this light. What interests us is whether the territorial and the personal principle were both present and in what way: how they intertwined and what kind of dynamic existed between them. Ultimately, we ask, which of the two occupied the more fundamental position - that is, which was primary and which acted as supplement.

\section{The Dynamic between the Territorial and Non-territorial Approaches and the Völkisch Conception of National Autonomy}

In order to answer these questions, we must first look at the Volksschutzgesetze as an ostensibly "pure" case of NTA and question their purely non-territorial character. Did the personal principle truly stand at its core? Formally speaking, beyond doubt: the legal proposition itself, its wording and its logic were unambiguously non-territorial and absent of any references to territory. The same applies also to the great majority of arguments put forward by various party-internal and external supporters of the bills, both in theoretical discussions and in the political debate. ${ }^{22}$ Whereas most of the contemporaries, including the proposers themselves, treated the Volksschutzgesetze as essentially non-territorial, the verdicts among historians have varied. Here, the assessment of Peter Haslinger is particularly worth pointing out. Contrary to many others (Majewski 2014, 346; Tóth, Novotný, and Stehlík 2012, 408; Petráš 2009, 250; Habel 2003, 365), Haslinger (2010, 117) designated the SdP demands as basically territorial, although nominally resting on the personal principle. Given that nothing within the bills themselves points in such direction, this position appears salient only if the possible unstated agenda and potential end-goals are drawn into calculation. The centrality of values such as "homeland," "soil," and "ethnic border" for the SdP, at which we have already pointed, indeed hardly speaks in favor of possibility of its ultimate aim being solely non-territorial autonomy.

Broadening of the perspective along these lines indeed brings forward solid indications that the actual considerations behind Volksschutzgesetze may have differed from the way they were formulated and might have included de facto territorial aims. The proposers' efforts to demonstrate the supposed compatibility of the bills with the Czechoslovak constitution and state structure speak for themselves. The main official proposer and probable co-author of the bills Ernst Kundt as early as 1936 rhetorically asked the Czechoslovak Prime Minister, who had stated that autonomy was out of question: "You are speaking about territorial autonomy, but we know very well that there is a different kind of autonomy. Must it necessarily be territorial?" 33 The lack of references to territory in the legal bills and their groundedness in the personal principle may thus also have served to give the impression of a "lesser" autonomy, a less "problematic" and "benign" solution along the lines of the Estonian Law on Cultural Autonomy and thus compatible with the Czechoslovak unitary state model.

This becomes especially clear, if we look at the claims put forward by legal experts standing close to the SdP after the bills had been presented. Their argument was that the Volksschutzgesetze represented merely implementation laws to the provisions already contained in the Czechoslovak constitution and its preamble. As Ernst Swoboda, a law professor at the German university in Prague and self-declared co-author of the bills (Osterkamp 2009, 202) put it, they served to realize the "leading thoughts" contained in the constitution (Swoboda 1937, 574-575). The crucial argument thereby was that, aligning itself to the article 91 , which referred to the freedom of association (allowing for creation of autonomous associations and determination of their spheres of discretion via special laws), and at the same time not making any references to territory the Volksschutzgesetz did not stand in conflict with the principle of (territorial) unity and indivisibility of the state. 
Observed from this perspective, the reasons for choosing a non-territorial platform instead of a territorial one could well be interpreted as primarily opportunistic and practical, motivated by a search for a legal form that would at least ostensibly be in line with the Constitution. When observed within the broader context of SdP aims and in light of later statements by the protagonists, the Volksschutzgesetze might however also be interpreted as maximalist demands, or more precisely: demands with a maximalist potential. This potentially maximalist character can be seen both in the scope of envisaged self-rule, as well as the fact that the non-territorial foundations did not $a$ priori negate the possibility of instituting territorial autonomy in nationally homogenous areas to achieve fullest extent of national self-rule. While not openly stated in the bills themselves, there are several indications that suggest the possibility of such unstated end-goals. Without making any explicit mention of territorial aims, Rudolf Schicketanz, the SdP legal advisor, publisher of the party daily Zeit and probable co-author of the bills ${ }^{24}$ argued that they were not "autonomist proposals in the ordinary sense." Rather, they aimed to create a basic platform, on which "self-rule or autonomy of all the nationalities can be built." ${ }^{25}$ Rudolf Sandner similarly described the recognition of the national group as a legal person as "the first and decisive step." It was however "no secret" where "our demands aimed in the end result": "We continue to believe that the internal affairs of the state can ultimately only be stabilized by granting self- rule to the nations that live in the state and are compactly settled" (Die Zeit, December 2, 1937). The proposer of the first Volksschutzgesetz Kundt went even further and explicitly stated the possibility for eventual territorial enhancement. After listing the wide range of competences that would have been left at discretion of the national associations, he wrote that after being instituted, their performance was going to show whether the state in future "by democratic-parliamentary means" and "through supplementary laws" could transfer "additional elements of autonomy to the individual nations, including the possibility of territorial self-rule" (Kundt 1937, 556).

Such a possibility for potential further arrangements of territorial nature appears particularly realistic when we consider the rising support for SdP among the German-speaking population, which was at that point already a hegemonic one. For the same very reason, the Czechoslovak authorities had been postponing the local elections as much as possible. When these finally took place in May 1938, the Sudeten German Party won around 90\% of German votes (Brandes 2005, 233). Practical hegemony on local level in compactly German speaking areas, resulting in factual rule over large territory via local administration by one single party, which would simultaneously comprise the Board of a legally instituted national association representing all Germans in Czechoslovakia, could have indeed resulted in a maximalist arrangement: a de facto territorial rule on a non-territorial legal platform. The potentials of achieving hegemony on the local levels for national self-rule were furthermore discussed by supporters of the SdP demands both in 1937 (Hugelmann 1937, 567) and 1938 (Wild 1938, 267).

What had been implicit to the 1937 demands as an unstated potential turned into a stated demand in those of 1938. The so-called Karlsbad points and their further elaboration in Skizze contained a maximalist program that combined territorial and non-territorial forms of autonomy. The two elements and their underlying principles intertwined in a way that aimed at the highest possible extent of self-rule that a national group may possess within a multinational state, ensuring that none of its members would be left out, regardless of their place of residence within the state territory. On the first sight, this appeared as an extensive form of territorial autonomy with a personal "supplement" for those Germans that lived scattered. Practically speaking, it is well possible to argue that this is what the Sudeten German Party had been aiming at from the beginning and also what would have been practically institutionalized, had the new legislation been adopted. Especially if observed through the rather common lens assuming the NTA as the necessarily "lesser" form of autonomy, such an interpretation may be arrived at quite naturally. By "lesser" we mean a form of autonomy which gives less self-rule to the national group, simultaneously also having a lesser impact on the integrity of the nation state. If observed from such angle, the maximalist character of the SdP demands indeed appears to have been defined by their fully revealed territorial potential. 
If, however, we adopt a different perspective and concentrate on the inner logic of the SdP demands and their theoretical underpinnings, a different kind of dynamic between non-territoriality and territoriality comes to the fore. A closer look of this kind reveals an essentially nonterritorial foundation, on which the entire edifice rested, reflecting a rather clear line of continuity between the Volksschutzgesetze and the Skizze. In both cases it was the constitution of the national group as a legal person, based on a national registry encompassing all the members of a given nationality that stood in the basis, acting as the first and fundamental pre-condition for autonomy. As Werner Hasselblatt $(1937,564)$ put it in regard to the Volksschutzgesetze: "united by the national association on the basis of the cadaster, the Volkspersönlichkeit is thus represented through personal law [personalrechtlich dargestellt]." In Skizze this fundamentally non-territorial concept was further upgraded with territorial arrangements, what had already been announced by Kundt in his speech immediately preceding the announcement of the Karlsbad demands: "The reorganization of the state must bebased on the national cadasters of the organized Volkspersönlichkeiten and the legal recognition of ethnic borders [Volksgrenzen]."26

Both Volksschutzgesetze (implicitly) and Skizze (explicitly) namely foresaw transformation of Czechoslovakia not only into a multinational state but into an ethnic federation. The goal was however not a federation of territories but one in which the nations themselves were to constitute the federal units, which was to be done on the basis of the personal principle. In case of the 1938 demands all this was explicitly stated: the explanations to the Karlsbad points specified their goal to be the actual implementation of the "principle of equality" to all the nationalities of Czechoslovakia, for which the "transformation of the Czechoslovak national state into a common state of all nations [Völker] and national groups [Volksgruppen] (federal state)" was necessary. ${ }^{27}$ The legal personality of the state (Staatspersönlichkeit) thus consisted of legal personalities of individual nations (Rechtspersönlichkeiten der Völker), which "encompass and represent all the members of the same nationality living in the state." 28

While already present in the program of Karl Renner $(1899,11,19)$ the constitution of nationalities as persons of public law had been a recurring demand raised within the interwar movement of European national minorities. In its liberal forms it aimed at securing collective cultural rights on a voluntary basis and facilitating transborder cultural cooperation without challenging the existing order of nation states. In case of the Sudeten German Party it however entailed substantially more than a demand for a legal recognition of national communities as voluntary associations of an essentially cultural character. It aimed at transforming the "democratic-individualistic state into a national-cooperative one" (Osterkamp 2009, 202), a non-territorially conceived union of largely self-ruling national communities with corporative inner structure and based on a binding and essentializing definition of nationality. In our opinion, such an arrangement represents a wider and more all-encompassing form of national autonomy than any federation of ethnic territories would have. It was thus precisely the non-territorial foundation that enabled the fully maximalist character of the SdP autonomist program both in its scope and type. For the same reason it is not surprising that the critique from the side of Czechoslovak constitutional and legal experts and officials from the Ministry of Justice went foremostly against its rootedness in the personal principle. ${ }^{29}$

The essential subordination of the individual to the national group, expressed via lack of accountability of the national associations towards their members was coupled with unclear delimitation of competences between the national associations and the central government. In the Austromarxist writings the latter had been clear cut: while the organs of national autonomy were to deal with cultural and educational matters of the respective nationality, the central parliament was to decide on matters of common good, important to all citizens, regardless of their nationality or what Renner had referred to as "the state-building interests and factors" (Renner 1899, 25-26). In clear analogy with a secularist argument, the ultimate aim was to de-nationalize the central institutions of the state via institutional separation between matters of particular nations (conceived as essentially cultural entities) and those of the common state. In a similar vein, concepts of national 
cultural autonomy that originated within the European Nationalities Congress - in particular those developed by Paul Schiemann - were framed. While by no means aiming to de-nationalize the young Estonian nation state, the 1925 Estonian Law on Cultural Autonomy, also essentially operated along the lines of divorcing the particularly national matters, confined to the sphere of culture and education, from the common matters of state politics. In all the listed cases national affiliation was furthermore a matter of free individual decision.

The listed illiberal traits of the Volksschutzgesetze that equally distinguished the Skizze (involuntariness concerning national belonging, scope of self-rule, lack of accountability) at the same time acted as the distinguishing marks of the illiberal adaptation of non-territorial autonomy of a völkisch type. The already mentioned Veiter, for whom personal autonomy represented the genuine form of autonomy (Veiter 1938, 59), deemed the Volksschutzgesetze "the hitherto most perfect legal form of national autonomy that best befits the nature of the nation and the state" (Veiter 1938, 221). The foreword to his extensive study on national autonomy published in early 1938 stated that the book stemmed from a "basic attitude" that was new and consciously separated the notion of national autonomy "from democratic slogans of a bygone era" (Veiter 1938, 5). As we shall see later, both the illiberal defining traits of the völkisch reconceptualization of national autonomy and its basic non-territorial underpinning were closely linked to a specific völkisch understanding of nationality that lay at its heart.

The key feature of the völkisch variant of national autonomy and the underlying nationality conception, distinguishing both the 1937 and 1938 SdP demands, was that the federated nationalities were perceived as the basic carriers of political sovereignty. In his already mentioned speech in April 1938, Kundt thus demanded recognition of the nationalities of Czechoslovakia as "personalities [Gesamtpersönlichkeiten] in public law" and as such "the only bearers of political will and popular sovereignty, from which the sovereignty of the state derives." ${ }^{0}$ The relationship of these fundamentally non-territorial entities towards national territory was one of owners towards their property - or, as Kundt put it:

We must be given the same legal and actual capacity to act; for this the state needs to legally recognize our national group as a unified legal person and legally protect our national territory, as well as our entire Besitzstand, as our inalienable and self-governing national property [Volkseigentum]. ${ }^{31}$

\section{The Two Intellectual Sources}

In order to gain a better insight into the inner logic of the SdP autonomist conceptions, the inherent interplay between territoriality and non-territoriality and the primacy of the non-territorial element, it is prudent to first try to trace the latter's origins and the path that had brought it there. What primarily interests us are the "principal minds" in the background - intellectual mediators that had facilitated its travel and adaptation. It is furthermore also pertinent to ask whether recourses to the Austromarxist theoretical concepts, had played any role and to what extent. From this perspective, two main intellectual streams can be identified, which had crucially informed the $\mathrm{SdP}$ autonomist conception and its non-territorial underpinning. It is simultaneously important to note already at this point that some of the probable co-authors of Volksschutzgesetze and Skizze from the leading SdP circle such as Ernst Kundt, Wilhelm Sebekowsky, and Hans Neuwirth had been linked to both of these streams. Perhaps not developers of original ideas but rather their second-hand dealers, these same men acted as the main protagonists in publicly promoting the 1937 bills - Kundt also having officially proposed two of them in the Parliament - as well as in negotiating the 1938 demands with the Czechoslovak government.

The first of the mentioned streams developing within the Sudeten German Party itself, whose understanding of nationality demonstrated clear preponderance of non-territoriality. In particular 
this pertained to the ideas of the Kameradschaftsbund (KB), an elitist society of young nationalist intellectuals, which at least up to 1937 represented the leading and most influential circle in the SdP and among other included Sebekowsky, Neuwirth and Kundt in its broader ranks. Inspired primarily by the universalist philosophy of the Viennese professor Othmar Spann, their ideas revolved around the notions of a decentralized, corporatist, holistic, and hierarchically organized "organic state" and that of the Sudeten German "tribe" - Stamm or Stammeskörper. While the former was modelled on an idealized image of a medieval German Reich, organically binding multiplicity of nationalities in a hierarchical way and giving them room for "fully developed selfrule" (Brand 1933, 17), the latter stood for a special body within the German nation, embodying "German nature in a special way" that corresponded to the Sudeten uniqueness (Brand 1935a, 6) and having a special historical mission of mediating between Germandom and Czechdom (Cornwall 2012, 188-189).

The antimodernist, backwards looking ideology of the Kameradschaftsbund, seeking examples in a mythicized past entailed a holistic and organicist approach towards various spheres of human life, also reflecting in categorical rejection of most of the modern political concepts. This also pertained to the analytical distinction between territorial and personal autonomy. Instead, they envisaged it in terms of "complete autonomy" (Gesamtautonomie), as "a form of statehood especially suited to the particular national group [eine der Volksgruppe arteigene Staatlichkeit]" organically binding elements of both (Heinrich 1931, 139). In the words of Walter Heinrich (1931, 140), a prominent KB ideologist and developer of the "organic state" theory, "the question, whether the principle of the personal or the territorial autonomy should be chosen" was only of secondary importance: "The highest principle is: the national bodies [Volkskörperschaften] are the carriers of [national] life [des Eigenlebens] - whose all-round development can be understood as Gesamtautonomie." While the notion of Volkskörperschaft clearly expresses the basic non-territoriality, the Gesamtautonomie simultaneously provides a possible key towards understanding the inevitable intertwinement between both organizational and legal principles within the ideology of the SdP.

In contrast to the "homegrown" particularist ideas of the $\mathrm{KB}$, centered on the specificity of Sudeten German "Stamm" and the Bohemian framework, the second stream stemmed from the international arena of minority activism. It was foremostly the European Nationalities Congress (ENC), a pan-European non-governmental organization, representing national minorities, where intellectual exchange between minority politicians and activists and legal experts engaging in nationality law took place. After 1933 the ENC underwent a transformation from a profoundly international and predominantly liberal forum into an instrument of German nationalist and revisionist foreign politics, which also reflected in the ideas and discourses promoted within its framework. This coincided with the virtual dominance in the German ENC representation by the Sudeten German Party members from 1935 onwards. Involvement of all the key protagonists in the ENC, along with their claims that the Volksschutzgesetze provided a general template for solving the European minorities' question, reflecting "insights of all the previous European Nationality Congresses" (Kundt 1937, 552), directly hints at the possibility that they were a product of a broader endeavor, in which the German experts on nationality law (Nationalitätenrecht, Volksgruppenrecht) played a crucial role. Their aim, stemming from the rejection of the existing minority protection based on individual rights, was to develop special legal frameworks for ethnic collectivities that were to be ultimately integrated into international law (Wheatley 2017, 777).

Hans Neuwirth, one of the later key protagonists in promoting the SdP autonomist demands and negotiating with the Czechoslovak government - as well as possible co-author (Luh 1988, 279; Novák 1987, 125) - held a speech at the 1936 European Nationalities Congress, which reflected this agenda clearly. The new nationalities law, Neuwirth $(1936,19)$ argued, was supposed to be "fundamentally different [...] from what the minority treaties are today" and rest on the legal recognition of the "given ethnic groups as Volkspersönlichkeiten" (Neuwirth 
1936, 15). While not necessarily linked to "a question of changing the territorial status" this inevitably implied new "forms in state law and also in intergovernmental law," Neuwirth (1936, 14) emphasized. "New nationalities law" was also a term explicitly used in a document that had originated within the SdP Office for Nationalities and League of Nations Affairs [Amt für Nationalitäten und Völkerbundfragen $]^{32}$ and aimed at substituting the existing minority treaties and providing an all-encompassing, binding system for entire Europe. ${ }^{33}$ Most striking in this document was the similarity to the main principles, provisions and even wording of the Volksschutzgesetze. There were also a couple of notable differences, including an explicit mention of the possibility for territorial autonomy, should certain conditions be fulfilled. The fundamental significance of Volkskörperschaft and Rechtspersönlichkeit however revealed a clearly non-territorial basis and the same inherent logic that was at play in the later SdP autonomist demands. ${ }^{34}$ The summit of SdP dignitaries [Amtswaltertagung] taking place in June 1936 in Eger/Cheb demanded to adjust the nationality law to the effect that recognized "the national groups and their responsible leaderships as a whole [...] as Volkspersönlichkeiten." 35

Same kinds of arguments could also be found in the explanations by Kundt (1936, 85-95) who later claimed that the Volksschutzgesetze provided a general platform for accommodating national diversity, relevant for all states and containing principles for "a just international order" (Kundt 1937, 559). Apart from being the main protagonist during 1937-38 dealings, Kundt had also been active in the framework of the international minority movement, representing the Sudeten German group in the Verband der deutschen Volksgruppen Europas, serving as a board member in the German League of Nations Union and taking part in the European Nationalities Congresses. Moreover, he also served as the director of the Deutschpolitische Arbeitsamt, a non-partisan organization of all non-Marxist German parties in Czechoslovakia, whose purpose was to coordinate their politics, particularly in the field of international minority complaints and participation in international forums (Neuwirth 1962, 143).

One of the key developers of the "new nationalities law," who in our opinion crucially influenced the content of the SdP demands at the same time fulfilling an important mediating role, was Hermann Raschhofer. An expert of nationality law from the University of Göttingen, Raschhofer demonstrated a strong and lasting attachment to the Bohemian lands and a profound interest in the nationalities question there. Persistently engaging for the Sudeten German cause he had been acting as a legal advisor to the SdP leadership at least since $1934,{ }^{36}$ wrote in open support of Volksschutzgesetze (Raschhofer 1937a, 536-549), and was present at the sessions of the SdP working committee for the nationalities statute during the 1938 negotiations with the Czechoslovak government. A look into his theories of nationality law and his conceptualization of Volkspersönlichkeit moreover reveals notable similarities and common points with the basic tenets of the SdP autonomist demands. The crucial commonality thereby lay in both the relationship and dynamic between the territorial and non-territorial elements - that is the territorial and the personal principle. In Raschhofer's autonomy conception, the latter acted as fundamental and the former as potential addition, should the specific circumstances allow for and demand it. If the conditions were favorable enough - as in case of Sudeten Germans for instance - territorial autonomy may be introduced as a higher, more developed form, which however does not negate the non-territorial basis. The constitution of a collective body, comprising all the members of a given nationality, regardless of their place of residence within state borders, would always be there as the primary and basic form. This was the case because nationality law as such was something essentially nonterritorial:

Characteristic for every nationality law is that it applies to persons [sein personeller Geltungsbereich] [...] This stems from the nature of the subject of such law. [...] Consequently, it needs to be ascertained and its scope of validity defined with regard to persons [and not territory] [Dadurch ergibt sich die Notwendigkeit der Erfassung und Geltungsbegrenzung personeller Art von selbst]. (Raschhofer 1931, 78) 
Raschhofer had for a longer time been an advocate of non-territorial autonomy and as early as in his 1931 monograph on the nationality law wrote that "lacking compact territorial settlement can not be a sufficient reason for denying the constitution of a nationality as a legal body" (Raschhofer 1931, 61). For that same very reason, he stressed the necessity of introducing institutions such as national registries and national electoral classes in multinational states (Raschhofer 1931, 79, 132-134, 155). Raschhofer's monoghraph furthermore made direct references to Renner and Bauer, especially the former, whom he extensively cited, also pointing out important parallels between his own and Renner's theories (Raschhofer 1931, 81-82, 145). He moreover made numerous, mainly positive references to the old Austrian national compromises, particularly the Moravian one, which he deemed "the hitherto most complete design or arrangement [Ausgestaltung] - of the nationality law” (Raschhofer 1931, 81).

On the other hand, Raschhofer however deemed the pre-war compromises a half-way solution, stressing the need for a more developed nationality law that would have provided all the nationalities in multiethnic states such as Czechoslovakia with a fair amount of "national political agency [volkspolitische Handlungsfähigkeit]" (Raschhofer 1938, 90-91). In the core of his legal theory namely stood the pseudo-Rousseauan notion of "sovereign Völker," entities of essentially political character, whose existence came before those of states. It was thus Volk as ethnos and not Volk as demos (Staatsvolk), that acted as the primary carrier of sovereignty and political will. In Central Europe, according to Raschhofer, the "abstract people envisaged by Rousseau" had "taken a concrete völkisch shape" (Raschhofer 1938, 90). While in mononational states the two conceptions of Volk largely corresponded to each other, this essentially meant that the multinational one consisted not of one sovereign Volk, but of a number of sovereign Völker. This approach largely corresponded to the principles guiding the Volksschutzgesetze with their omnipotent national associations, as well as the explicit framing of the Karlsbad demands/Skizze in terms of a federation of nationalities. Encompassing the entirety of co-nationals, regardless of their place of residence, the sovereign Völker also acted as essentially non-territorial entities - subjects, which were not territorially ascertainable (Raschhofer 1931, 78). Essential elements of "Raschhoferian" approach were clearly present in both Kundt's considerations about national autonomy, ${ }^{37}$ as well as those by Sebekowsky (Rundschau, March 27, 1937).

\section{The Notion of Volkspersönlichkeit and the Thought of Max Hildebert Boehm}

Common to both intellectual streams was however an underlying basic understanding of nationality, which was an illiberal, völkisch, and organicist one. The same kind of nationality conception was also held by the SdP and lay at the heart of its autonomist scheme along with its basic nonterritorial underpinning. It conceived the nation as special "being" (Wesen) with own "soul," "purposes," and "will" - or in the words of the key KB ideologist Walter Brand (1935b, 11) a "living whole" with "vital necessities and natural vital rights" of its own. A collectivity which is in itself and for itself substantially more than a sum of its members, whose individual rights and interests are furthermore fully subordinated to those of the group.

Particularly important from this perspective was the notion of Volkspersönlichkeit, a recurring concept in both the KB thought and the discourse linked to the new nationality law. At the same time it had from its very inception formed part of the SHF/SdP rhetoric, occupying a prominent place in Henlein's speeches (1937, 9-10; 1939, 17-18). Moreover, the Karlsbad demands themselves were presented as a logical outcome of the modern Czech-German problem that had commenced in the year 1848 when the two competing Bohemian nations "crystallized and consolidated" into "conscious Volkspersönlichkeiten." 38 The notion was also employed in Skizze, which aimed at securing the "rights and freedoms of the Volkspersönlichkeiten themselves, amongst each other and vis-à-vis the state as their shared legal association." ${ }^{39}$

Whereas in the language of romantic nationalism Volkspersönlichkeit had commonly referred to the "national character," the expression of the "national soul" through language, culture, art, 
mentality, morality and legal sense, its interwar conceptualizations within völkisch discourse entailed more substantial meanings. Referring to the ethnic group itself, conceived as collective personality. Comprising the entirety of kin, regardless of their spatial location within the state territory, it acted as a comprehensive, "all-encompassing," and self-enclosed entity (Wesen) (Cf. Raschhofer 1937b, 372-373). Most importantly, it was an active agent in history, or as the leading völkisch theoretician of the time, commonly seen as the "pioneer," who anticipated ethnopolitics (Haar 2000, 27), the sociologist Max Hildebert Boehm $(1932,308)$ had put it: "Volkspersönlichkeit itself is a principle of historical life."

Centering around the notion of "independent Volk," Boehm's theories, had an enormous influence on the interwar völkisch thinking. Together with the ethnographer Karl Christian von Loesch Boehm in 1925 co-founded and afterwards led the "Institut für Grenz- und Auslandsstudien" in Berlin, whose activities were directed at challenging the post-WWI nation state order in East Central Europe, informing the work of numerous German-speaking legal theoreticians and minority politicians across the region. Both Boehm and Loesch politically counted among "traditionalists" from the "young conservatives" camp. Both however also turned Nazi fellow travelers after Hitler's takeover of power, adjusting their theories accordingly (Cf. Korb 2014, 189 and Postert 2015,36) - a pattern equally distinctive for legal scholars such as Veiter (Behal 2010, 9) or Raschhofer, who had served as Boehm's assistant during 1928-30.

Counterposing the "state principle" with the "ethnic principle" (das volkliche Prinzip), Boehm conceptualized the Volk as an entity of essentially political nature, "independent, politically and historically active agent [eigenständige, in die Politik und Geschichte hinwirkenden Wesenheit]" (Boehm 1932, 9), which was at the same time primordial and whose organization was more fundamental than that of the state. It was the ethnic nations and not states that acted as the primary agents in European politics and Loesch therefore called for the "recognition of nations [Völker] as Volkspersönlichkeiten and as such as the natural basis of the new Europe" (Loesch 1926, 50 in Salzborn 2005, 67). At the same time such a conceptualization of nationality was marked by a clear preponderance of non-territoriality and fitted much better with the personal than with the territorial principle. Boehm himself openly recognized this as early as 1934 writing that "notwithstanding their Marxist shortcomings [trotz ihrem marxistischen Pferdefu $\beta$ ], the merit of Renner's and Bauer's ideologies [...] lies in the fact of having clearly demonstrated the inadequacies of territorial generic solutions [territorialer Patentlösungen]" (Boehm 1934, 766).

Boehm's theories had widely resonated among both Volksgruppenrechtler and German minority activists around East Central Europe, leaving a lasting imprint on their nationality discourse. Sudeten German völkisch movement of the 1930s, stressing the political primacy of the Volk towards the state, from which the SdP had originated as its political representation, was no exception here (Cf. Nittner 1984, 344). A letter sent by the SdP Amt für Nationalitäten und Völkerbundfragen to Hasselblatt in November $1935^{40}$ thanking him for sending them a copy of "Das eigenständige Volk" thereby confirms that SdP was familiar with Boehm's theories as early as 1935 and that the channel through which they acquainted themselves with them had been the international networks of minority activism.

\section{Conclusions}

The "holy right to the independence of the Volk" was also evoked in an article published in October 1938, immediately after the Munich agreement and following annexation of the Czechoslovak border regions by Germany and Hungary, in Nation und Staat under the title "Legal Safeguarding of Inter-Ethnic Relations through National Self-Rule [Rechtliche Sicherung zwischenvölkischer Beziehungen durch nationale Selbstverwaltung]" (Stegmann 1938). The author, H. Stegmann, from the prominent Baltic German family ${ }^{41}$, discussed the autonomist programs that the Sudeten German Party had put forward and advocated during 1937-38. By then obviously irrelevant for the Czechoslovak framework, the Volksschutzgesetze and the Skizze were presented as legal templates 
for peaceful accommodation of ethno-national diversity within European states through solving "the eternal European problem of nation and state" (Stegmann 1938, 32). Most importantly, the text provided a concise, yet thorough outline of the main tenets and intellectual influences on which the autonomist proposals were built, particularly illuminating the intertwinement of the territorial and non-territorial aspects of autonomy inherent to them and their mutual interplay. Judging that the opposition and choice between the territorial and non-territorial forms of autonomy depended primarily on "geopolitical realities," whereby the pattern of settlement acted as decisive (Stegmann 1938, 27), and simultaneously pointing out the explicit combination of both within Skizze (Stegmann 1938, 30-31), Stegmann however also emphasized the "demand for a national selfgoverning body [...] encompassing the entire state territory" as the most basic tenet on which both autonomist programs had rested. It simultaneously presented an essential condition for any kind of nationality law. Stegman thereby made references to Raschhofer and to Sebekowsky in particular, who "had written [...] that the key to the solution of the national problem lay in the organized independence of the living national body [in der organisierten Eigenständigkeit der lebendigen Volkskörper]" (Stegmann 1938, 28).

The demands for national autonomy that the Sudeten German Party put forward during 193738, aiming at far-reaching reorganization of Czechoslovakia along national lines, demonstrate a profoundly close interplay and dynamic between territorial and non-territorial elements. A closer scrutiny, however, also reveals the complexities of this relationship. It is possible to argue that the practical end-goal in both cases entailed territorial autonomist arrangements - an objective not at all surprising for a political movement, whose ideology had been so firmly and emotionally attached to the notion of national territory. While in the case of the 1937 Volksschutzgesetze, an ostensibly "pure" case of non-territorial autonomy, the maximalist combination of both forms of national autonomy had acted as an unstated potential, it turned into a stated demand in 1938. Territorial end-goals were however also coupled by a shared, essentially non-territorial underpinning as a closer look into the inner logic of the legal proposals and their intellectual background shows.

The specific völkisch and organicist understanding of nationality, to which the SdP adhered, namely manifested a clear preponderance of non-territoriality. This applied to both the main intellectual currents that had informed its conception of national autonomy: the legal scholarship engaging in developing a general system of nationality law, as well as the political thought of the Kameradschaftsbund circle, influenced by the philosophy of Othmar Spann. Both shared the fundamentally non-territorial notion of Volkspersönlichkeit (in case of the KB also Stammeskörper). Encompassing all the members of the national group, regardless of their place of residence within and potentially also beyond - the state territory this "ethnic personality" was simultaneously also conceived as the basic carrier of political will. Volksschutzgesetze and Skizze thus represented clear examples of illiberal (re-)conceptualization of national autonomy, informed by contemporary völkisch sociological, legal, and political thought. The interplay between the territorial and the personal principle that characterized them simultaneously shows how within autonomous and other arrangements for accommodating national diversity the two principles always operate in a certain relationship, whereby one of them always acts as fundamental. The case of SdP autonomist demands with their fundamentally non-territorial underpinning ultimately also reveals the adaptability of the idea of NTA, which had been flexible enough to be adapted to the language of a völkisch-nationalist ideology. Simultaneously, it hints both at the winded path of its travel, as well as at the complexity and possible multiplicity of its origins.

Disclosures. None.

Financial Support. The writing of this article was supported by funding from the European Research Council (ERC) within the project "Non-territorial Autonomy: History of a Travelling Idea", no. 758015. 


\section{Notes}

1 CZ-NA, NAD 503. K. 36, Skizze über Neuordnung der innerstaatlichen Verhältnisse auf Grundlage der 8 Punkte aus der Rede des Vorsitzenden der Sudetendeutschen Partei, Konrad Henlein, in Karlsbad am 24. April 1938 [hereinafter Skizze].

2 Ernst Eisenlohr an Auswärtiges Amt, 4.2.1938. In Akten zur deutschen auswärtigen Politik, Serie D, Bd. II.,94-95; TNA FO 371/22339, 28, Basil Newton: Czechoslovakia. Annual Report, 1937 (13.1.1938); Zpověd' K.H. Franka: podle vlastních výpovědí v době vazby u krajského soudu trestního na Pankráci. Praha 1947, 25.

The above listed sources have been brought to my attention by dr. René Küpper (CC, Munich), to whom I am very grateful.

3 Gesetz über die Haftung des Staates und anderer öffentlich-rechtlicher Verbände für Schäden, die durch ihre Organe bei Ausübung der Amtswirksamkeit verursacht werden gemäß $\$ 92$ der Verfassungsurkunde proposed by Karl Hermann Frank; Gesetz zur Verwirklichung des in den $\$ \$ 106$ und 128 der Verfassungsurkunde ausgesprochenen Grundsatzes der Gleichberechtigung in allen Zweigen des öffenlichen Dienstes proposed by Karl Hermann Frank; Gesetz über das Klagerecht vor dem Verfassungsgericht proposed by Ernst Kundt.

4 Poslanecká sněmovna N. S. R. Č. 1937. IV. volební období. 5. zasedání. Překlad. 897. Návrh poslance E. Kundta na vydání zákona na ochranu národnostních práv zřízením veřejnoprávních svazů (zákon na ochranu národností).

5 B Poslanecká sněmovna N. S. R. Č. 1937. IV. volební období. 5. zasedání. Překlad. Návrh poslance dr Köllnera na vydání zákona o národnostní příslušnosti státních občanů a o národnostních katastrech.

6 Ernst Swoboda, professor of Law on the Prague German University and probable co-author of the bills, explained the purpose of the second bill as follows: "Um die Ehrlichkeit des Rechtes zu sichern, muß dafür Sorge getragen werden, daß sich auch jeder Volksgenosse ehrlich zu seiner Nation bekenne, daß er darin nicht nur nicht behindert, sondern dazu verpflichtet wird. Dazu soll das Gesetz über den nationalen Kataster dienen" (Swoboda 1938, 27)

7 Boyer and Kučera rightly point out the irrevocable character of national affiliation, yet go too far by stating that this necessarily implied conceptualization of nationality as "racial community" in the Nazi vein.

8 Poslanecká sněmovna N. S. R. Č. 1937. IV. volební období. 5. zasedání. Překlad. Návrh poslance dr Köllnera na vydání zákona o národnostní př́slušnosti státních občanů a o národnostních katastrech.

9 The justification of the first bill designated the national association "as carrier of the will of its national group [ ... ] authorized and obliged to represent its interests." - CZ-NA, NAD 503, K. 52, Volksschutzgesetze - Volltext der Anträge mit Begründungen.

10 Elizabeth Meta Wiskemann (1899 - 1971) was a British journalist and historian specializing in German affairs. The results of her study on the Germans in Czechoslovakia, which had been commissioned by the Royal Institute of International Affairs, were published under the title Czechs and Germans in 1938.

11 CZ-NA, NAD 503, K. 53, Skizze (English version).

12 CZ-NA, NAD 503, K. 53, Zweck des Memorandums.

13 CZ-NA, NAD 503, K. 53, Die Forderungen von Karlsbad 1938.

14 Ibid.

15 Ibid. and CZ-NA, NAD 503, K. 53, Zweck des Memorandums.

16 CZ-NA, NAD 503. K. 36, Skizze.

17 Ibid. and Tóth, Novotný, and Stehlík 2012, 421.

18 CZ-NA, NAD 503. K. 36, Skizze.

19 Ibid.

20 Ibid. 
21 CZ-NA, NAD 503, K. 53, Skizze (English version).

22 See for instance the assertions by Kundt and Gustav Peters during the November 1937 debate in the Budget Council of the Czechoslovak House of Representatives that they wanted solely personal autonomy (Prager Abend, 18. 11. 1937).

23 CZ-NA, NAD 503 Sudetendeutsche Partei, K. 52, "Mahnungen an das Gewissen der Verantwortlichen" (10. 11. 1936).

24 A special issue of the Illustrierte Beobachter, published immediately after the "liberation" of Sudetenland in October 1938 wrote that drafting the Volksschutzgesetze had been "wesentlich sein Werk" (Illustrierte Beobachter, Sondernummer Befreites Sudetenland, Oktober 1938).

25 CZ-NA, NAD 503/0/1, K. 21, Dr. R. Schicketanz, "Die Grundegedanken der Gesetzesanträge der Sudetendeutschen Partei."

26 CZ-NA, NAD 503, K. 53, "Die bisherige Rechtsentwicklung und unsere grundsätzlichen Forderungen für eine Rechtsordnung." Rechtspolitisches Referat gehalten von Abgeordneten Ernst Kundt (Karlsbad, 23. 4. 1938) [hereinafter Referat Kundt (23. 4. 1938)].

27 CZ-NA, NAD 503, K. 53, Zweck des Memorandums.

28 Ibid. and CZ-NA, NAD 503, K. 36, Skizze.

29 CZ-ANM, I. Derer, K. 11 (526), Vorschläge für die nationale Selbstverwaltung, vom 16. 6. 1938; Tóth, Novotný, and Stehlík 2012, 423-425; Osterkamp 2009, 233.

30 CZ-NA, NAD 503, K. 53, Referat Kundt (23. 4. 1938).

31 Ibid.

32 Amt für Nationalitäten- und Völkerbundfragen at the SdP headquarters had been established in 1935, quickly becoming "a center for managing the Sudeten question as a 'European business"”, with links to other German (and non-German) minorities (Cornwall 2012, 190).

33 CZ-NA, NAD 503/0/1, K. 21, Allgemeines Nationalitätenrecht.

34 Ibid.

35 CZ-NA, NAD 503, K. 37, Nachrichten des Verbandes der deutschen Volksgruppen in Europa, 1936-1938 Nr. 350, 26. 6. 1936.

36 Karl Hermann Frank an den Reichserziehungsminister Bernhard Rust am 12. 4. 1939 (in Král 1964, 387-388).

37 CZ-NA, NAD 503, K. 53, Referat Kundt (23. 4. 1938).

38 CZ-NA, NAD 503, K. 53, Zweck des Memorandums.

39 CZ-NA, NAD 503. K. 36, Skizze.

40 CZ-NA NAD 503, K. 36, ANV SdP to Werner Hasselblatt, 28. 11. 1935.

41 Authorship not established - possibly Helmut Stegmann, lawyer and city councillor (19201933) from Riga.

\section{References}

Behal, Brigitte. 2010. "Der Feldkircher Jurist Theodor Veiter - katholisch und deutsch-national. Hintergründe einer österreichischen Karriere 1929-1994.” Lecture organized by J.-A.-Malin-Gesellschaft, Dornbirn, June 16.

Boehm, Max Hildebert. 1932. Das eigenständige Volk. Einführung in die Elemente einer europäischen Völkersoziologie. Göttingen: Vandenhoeck \& Ruprecht.

Boehm, Max Hildebert. 1934. "Krise und Ausklang.” In Das Nationalitätenrecht des alten Österreich, edited by Karl Gottfried Hugelmann, 739-770. Wien-Leipzig: Wilhelm Braumüller.

Bohemia. 1937. "Die Initiative der SdP." April 29.

Boyer, Cristoph, and Jaroslav Kučera. 1997. “Alte Argumente Im Neuen Licht.” Bohemia 38 (2): 358-68.

Brand, Walter. 1933. "Volkstum und Staat im Mittelalter. Eine geistesgeschichtliche Studie.” Die Junge Front 4 (1): 13-17.

Brand, Walter. 1935a. Die Idee des "sudetendeutschen Stammes": Verschweizerung, Volksverrat oder sudetendeutsches Schicksal? Prag: n. p.

Brand, Walter. 1935b. "Volksgruppe, Volksgemeinschaft und Staat." Nation und Staat 9 (1): 8-13.

Brandes, Detlef. 2005. "Besinnungsloser Taumel und maßlose Einschüchterung'. Die Sudetendeutschen im Jahre 1938.” In Jahrbuch der Heinrich-Heine-Universität Düsseldorf 2004, edited by Joseph A. Kruse and Sabine Brenner-Wilczek, Sabine, 221-240. Düsseldorf: Heinrich-Heine-Universität.

Brandes, Deflef. 2010. Die Sudetendeutschen Im Krisenjahr 1938. München: Oldenbourg. 
Cornwall, Mark. 2012. The Devil's Wall: The Nationalist Youth Mission of Heinz Rutha. Cambridge, MA: Harvard University Press.

Gebel, Ralf. 1997. “Zwischen Volkstumskampf Und Nationalsozialismus.” Bohemia.38 (2): 376-85.

Haar, Ingo. 2000. Historiker im Nationalsozialismus. Deutsche Geschichtswissenschaft und der "Volkstumskampf” im Osten. Göttingen: Vandenhoeck \& Ruprecht.

Habel, Fritz Peter. 2003. Dokumente zur Sudetenfrage. Unerledigte Geschichte. München: Langen Müller.

Haslinger, Peter. 2010. Nation Und Territorium Im Tschechischen Politischen Diskurs 1880-1938. München: Oldenbourg.

Hasselblatt, Werner. 1937. “Die Sudetendeutschen Gesetzanträge Und Die Nationalitätenbewegung.” Nation und Staat 10 (9): 560-65.

Heinrich, Walter. 1931. "Kritisches Und Aufbauendes Zur Frage Der Autonomie Und Der Sogenannten Minderheiten." Die Junge Front 2 (5): 131-41.

Henlein, Konrad. 1937. Konrad Henlein Spricht: Reden Zur Politischen Volksbewegung Der Sudetendeutschen. Edited by Rudolf Jahn. Karlsbad: Frank.

Henlein, Konrad. 1939. Heim Ins Reich: Reden Aus Den Jahren 1937 Und 1938. Edited by Ernst Tscherne. Reichenberg: NS Gauverlag Sudetenland.

Houzvicka, Václav. 2016. Czechs and Germans, 1848-2004: The Sudeten Question and the Transformation of Central Europe. Chicago: University of Chicago Press.

Hugelmann, Karl Gottfried. 1937. “Verbände Öffentlichen Rechtes Zum Schutze Der Volkstumsrechte.” Nation und Staat 10 (9): 566-71.

Hünger, Heinz. 1938. “Kurzbiographien: Henlein, Frank, Kundt, Sebekowski, Köllner, Schickedanz,” Illustrierte Beobachter, Sondernummer Befreites Sudetenland, October.

Jesser, Franz. 1926. "Volkskunde und Politik.” Akademische Blätter 41 (1).

Korb, Alexander. 2014. "Dissimilation, Assimilation and the Unmixing of Peoples: German and Croatian Scholars Working towards a New Ethno-Political Order, 1919-1945.” Transactions of the RHS 24: 183-203.

Kracik, Jörg. 1999. Die Politik des deutschen Aktivismus in der Tschechoslowakei 1920-1938. Frankfurt am Main: Peter Lang.

Kučera, Jaroslav. 1999. Minderheit im Nationalstaat: Die Sprachenfrage in den tschechisch-deutschen Beziehungen 1918-1938. München: Oldenbourg.

Kundt, Ernst. 1936. "Volkstumsrecht in der Völkerrechtlichen Entwicklung." Nation und Staat 10 (2-3): 78-95.

Kundt, Ernst. 1937. "Entwicklungsgründe, Bedeutung und Inhaltsgrundsätze unserer Gesetzesanträge.” Nation und Staat 10 (9): 550-59.

Kuzmany, Börries. 2016. "Habsburg Austria: Experiments in Non-territorial Autonomy.” Ethnopolitics 15 (1): 43-65.

Leoncini, Francesco. 1988. Die Sudetenfrage in der Europäischen Politik: von den Anfängen bis 1938. Essen: Hobbing.

Lipscher, Ladislav. 1981. "Die parteipolitische Struktur der Minderheiten und ihre staatsrechtlichen Vorstellungen zur Lösung der nationalen Frage in der Tschechoslowakei (1918-1930).” Bohemia 22 (2): 342-80.

Loesch, Karl C. von. 1926. Staat und Volkstum. Berlin: Deutscher Schutzbund Verlag.

Luh, Andreas. 1988. Der deutsche Turnverband in der ersten tschechoslowakischen Republik.Vom völkischen Vereinsbetrieb zur volkspolitischen Bewegung. München: Oldenbourg.

Majewski, Piotr M. 2014. Sudetští Němci 1848-1948. Historie jednoho nacionalismu. Praha: Conditio Humana.

Neuwirth, Hans. 1936. "Reale Rechtsstaatlichkeit - Rechtspersönlichkeit der Volksgruppen.” Nation und Staat 10 (1): 13-22.

Neuwirth, Hans. 1962. "Der Weg der Sudetendeutschen von der Entstehung des Tschechoslowakischen Staates bis zum Vertrag von München.” In Die Sudetenfrage in Europäischer Sicht, 122-179. München: Verlag Robert Lerche.

Nittner, Ernst. 1984. "Hitlers Machtergreifung und die sudetendeutsche Einigungsbewegung." Bohemia, 25: 333-361.

Novák, Otto. 1987. Henleinovci proti Československu: z historie sudetoněmeckého fašismu v letech 1933-1938. Praha: Naše Vojsko.

Osterkamp, Jana. 2009. Verfassungsgerichtsbarkeit in Der Tschechoslowakei (1920-1939). Verfassungsidee - Demokratieverständnis - Nationalitätenproblem. Frankfurt Main: Vittorio.

Petráš, René. 2009. Menšiny v meziválečném Československu: Právní postavení národnostních menšin v první Československé republice a jejich mezinárodněprávní ochrana. Praha: Karolinum.

Postert, André. 2015. “Der »Ruf der Jungen«: Max Hildebert Boehm und der junge Konservatismus in der Weimarer Republik.” INDES 4 (3): 29-37.

Prager Abend. 1937. November 18.

Prager Presse. 1937. “'Psychose des Nationalismus’ Debatte über die 'Volksschutzgesetze’ der SdP.” November 13.

Raschhofer, Hermann. 1931. Hauptprobleme Des Nationalitätenrechts. Stuttgart: Enke.

Raschhofer, Hermann. 1937a. “Die Nationalitätrechtlichen Gesetzanträge Der Sudetendeutschen Partei." Zeitschrift für ausländisches öffentliches Recht und Völkerrecht 7 (1): 536-49.

Raschhofer, Hermann. 1937b. “Nationalität als Wesen und Rechtsbegriff.” In 25 Jahre Kaiser Wilhelms-Gesellschaft, Bd. 3: Die Geisteswissenschaften, 329-373. Berlin: Springer.

Raschhofer, Hermann. 1938. "Wechselrede." In Dritte Sudetendeutsche Tagung Für Öffentliches Recht in Leitmeritz Am 16. Und 17. Oktober 1937. Vorträge Und Wechselrede, 89-92. Brünn: Rudolf M. Rohrer Verlag. 
Renner, Karl [Synopticus]. 1899. Staat und Nation. Zur österreichischen Nationalitätenfrage. Staatsrechtliche Untersuchung über die möglichen Principien einer Lösung und die juristischen Voraussetzungen eines Nationalitäten-Gesetzes. Wien: Dietl. Sandner, Rudolf. 1937. “Selbstverwaltung ist die einzige Lösung.” Die Zeit, December 2.

Salzborn, Samuel. 2005. Ethnisierung Der Politik. Theorie Und Geschichte Des Volksgruppenrechts in Europa. Frankfurt Main, New York: Campus.

Schiemann, Paul. 1937. "Nationalismus gegen Nationalismus. Zu den Anträgen der Sudetendeutschen Partei." Der Deutsche in Polen, July 25.

Sebekovsky, Wilhelm. 1937. “Grundzüge der sudetendeutschen Volkstumspolitik.” Rundschau, March 27.

Sobota, Emil. 1938. Národnostní autonomie v Československu? Praha : Orbis.

Stegmann, H.. 1938. "Rechtliche Sicherung zwischenvölkischer Beziehungen durch nationale Selbstverwaltung." Nation und Staat 12 (1): 25-32.

Stourzh, Gerald. 1985. Die Gleichberechtigung der Nationalitäten in der Verfassung und Verwaltung Österreichs 1848 - 1918. Wien: Verl. d. Österr. Akad. d. Wiss.

"Sudetendeutsche Heimatfront. 1933. Idee, Arbeit, Wille statt Programm und Worte." Junge Front 4 (10-11): 317-21.

Swoboda, Ernst. 1937. "Die Verfassungsmäßigkeit der von der Sudetendeutschen Partei eingebrachten Gesetzentwürfe zur Regelung der nationalen Verhältnisse." Nation und Staat 10 (9): 572-77.

Swoboda, Ernst. 1938. "Ehrliches Und Volksnahes Recht.” In Dritte Sudetendeutsche Tagung Für Öffentliches Recht in Leitmeritz Am 16. Und 17. Oktober 1937. Vorträge Und Wechselrede, 7-32. Brünn: Rudolf M. Rohrer Verlag.

Thiele, Rudolf. 1938. “Die Volksschutzgesetzanträge der Sudetendeutschen Partei vom Standpunkt der Verfassungsgrundsätze der Tschechoslowakei." Zeitschrift für osteuropäisches Recht 4 (8): 478-89.

Tóth, Andrej, Lukás Novotný, and Michal Stehlík. 2012. Národnostní menšiny v Československu 1918-1938: Od státu národního ke státu národnostnímu? Praha: Univerzita Karlova.

Veiter, Theodor. 1938. Nationale Autonomie: Rechtstheorie und Verwirklichung im positiven Recht. Wien/Leipzig: Wilhelm Braumüller.

Vierling, Birgit. 2014. Kommunikation als Mittel politischer Mobilisierung. Die Sudetendeutsche Partei (Sdp) auf ihrem Weg zur Einheitsbewegung in der ersten tschechoslowakischen Republik (1933-1938). Marburg: Herder-Institut.

Wheatley, Natasha. 2017. "Spectral Legal Personality in Interwar International Law: On New Ways of Not Being a State.” Law and History Review 35 (3): 753-787.

Wild, K. 1938. “Aufbau Der Volksgemeinschaft.” Volk und Führung 4 (6): 264-70.

Wiskemann, Elisabeth. 1938. Czechs and Germans. London: Oxford University Press.

\section{Collections of Published Sources}

Akten zur deutschen auswärtigen Politik 1918-1945; aus dem Archiv des deutschen Auswärtigen Amtes, Serie D, Bd. II: Deutschland und die Tschechoslowakei (1937-1938). 1950. Göttingen: Vandenhoeck \& Ruprecht.

Král, Václav. 1964. Die Deutschen in der Tschechoslowakei 1933-1947. Praha: Československá akademie věd.

Národni shromáždění republiky Československé 1935-1938, Poslanecká sněmovna, tisky. https://www.psp.cz/eknih/1935ns/ps/ tisky/index01.htm (Digitální repozitár̆ Parlamentu České republiky, Accessed April 16, 2021.)

\section{Archives}

Národní archiv České republiky (CZ-NA)

Archiv Národního muzea (CZ-ANM)

The National Archives Kew (TNA)

Cite this article: Mulej, O. 2022. Territorial and Non-territorial Aspects in the Autonomist Proposals of the Sudeten German Party, 1937-38. Nationalities Papers 50: 942-962, doi:10.1017/nps.2021.61 